\title{
Drinking beer and understanding organizational culture embodiment
}

\author{
Maria Tereza Flores-Pereira, Eduardo Davel and \\ Neusa Rolita Cavedon
}

Although organizational researchers have gained in terms of different perspectives of thought and reflexivity regarding the subject of organizational culture, they have neglected studying the embodied dimension of organizational culture. The purpose of this article is to use embodiment perspective to enlighten understanding of organizational culture. We do that by giving special attention to: a) a pioneering empirical anthropological study that deals with the culture-embodiment relationship and b) an organizational ethnography in which work colleagues engage in the after-work beer drinking ritual. This double emphasis suggests that organizational life become first meaningful in the experiential immediacy of employees and organization. In this very moment organizational culture signification is not yet representational, but perceptual. Thus, the main contribution of this research is to show that organizational culture is more than a cognitive-representational abstraction: it is also a perceptual-embodied experience.

KEYWORDS

alcoholic beverage - body - embodiment - ethnography experiential immediacy - organizational culture - organizational ritual - perceptual experience 


\section{Introduction}

It is widely accepted that organizational researchers know a great deal about organizational culture. There have been abundant explorations and debates on this theme that have opened up our understanding to different approaches, theoretical traditions, critical thinking, concepts and methodologies. Although organizational researchers have gained in terms of different perspectives of thought and reflexivity regarding organizational culture, they have neglected one key aspect of its dynamics: the human body. The body is capital in the practice of many cultural expressions, such as rituals, ceremonies, artifacts, values, and beliefs. But it is also fundamental for understanding what organizational culture is from an embodied point of view.

The purpose of this article is to acknowledge that the pre-reflective cultural process enriches organizational researchers' knowledge about organizational culture. By 'pre-reflective', we mean the embodied dimension of culture that is the cultural experience that precedes the mental process of cultural abstraction and representation. From this perspective the human body is more than a biological or socio-cultural object, it is the foundation of experience (Merleau-Ponty, 2005) and culture (Alves \& Rabelo, 1998; Csordas, 1988, 1994a, 1997). It means that we, as bodies, establish a relationship with a historical and cultural world that precedes reflective thought and culture as a system of representation. Before thinking and representing the world, we embody it.

In order to bring this understanding to the field of organization studies, we ground our research in two strategies. First, we capitalize on a pioneering empirical anthropological study by Csordas (1988) - 'Embodiment as a paradigm for anthropology' - that deals with the culture-embodiment relationship through the ethnography of a religious healing ritual. Then, we engage in an organizational ethnography conducted by one of the authors of this article $\left(\right.$ Mary $\left.^{1}\right)$, focusing on the ritual of beer drinking among work colleagues. Contrary to most anthropological and organizational research, we do not consider the ritual as a medium to unveil social functions and cultural symbolism (Curran, 1989; Geertz, 1973; Gennep, 1966; Turner, 1995). Inspired by Csordas's (1988) ethnography, we use it as a device to learn about organizational culture embodiment.

This article is structured as follows. In the first section, we discuss the (almost) absent presence (Dale, 2001) of the human body in organizational culture studies and the prevalence of the cognitive (representational) paradigm in organizational culture research (Strati, 1998). Next, we draw upon the fields of Philosophy, the Social and Human Sciences and review studies dealing with embodiment (Burkitt, 1999; Crossley, 1995; Merleau-Ponty, 2004, 2005), the cultural embodied experience (Alves \& Rabelo, 1998; Csordas, 
1988, 1994a, 1994b, 1997; Víctora, 1997) and the use of rituals as a fecund cultural category for a better apprehension of the embodied dimension of culture (Bell, 1992; Csordas, 1988). In the third section, we expose the experience of a participant observer in a non-official after-work beer drinking ritual that encourages the emergence of specific organizational cultural expressions. Finally, we discuss the pre-reflective cultural process underlying organizational life, showing that the use of embodiment perspective highlights a deeper level of understanding about organizational culture, one that takes place in the employees-organization experiential immediacy. We defend the idea that it is during this process that organizations become meaningful; that signification is not yet representational, but rather perceptual.

\section{How embodied is organizational culture?}

The human body has been disregarded as a key object of investigation in the field of organizational culture studies. Although indirectly, the body is quoted as one of the many organizational artifacts (Hatch, 1993; Martin, 2002; Schein, 1992) and as a component of rituals, rites and ceremonies (Martin, 2002; Trice \& Beyer, 1984). For example, Latouche (1983) suggests considering some body dynamics, such as gestures and customs, when analyzing organizational culture. Schein (1992), another example, suggests embedment of organizational culture in body dynamics such as dress code, manners of address and emotional displays. For Trice et al. (1984), organizational culture includes rites and ceremonies in which gestures are body movements that convey meanings. In none of these studies, however, the word 'body' is used in association with the thematic of organizational culture.

Martin (2002) sustains the only study in which we found a connection between the word 'body' (including 'embody') and organizational culture studies. The author stresses that photographs (of 'faces' and 'bodies'), the recording of voices and the filming of organizational actors can be used as research techniques, once the individual 'embodies' organizational culture. Although Martin (2002) selects the words 'body' and 'embody' to talk about the cultural phenomenon, the human body is still not used as a key object of organizational cultural investigation.

Although these organizational researchers do not go deeper into the investigation of the relationship between body and organizational culture, they introduce an idea that has been worked in anthropological studies for a long time: the use of the body as an empirical object for understanding culture (Boltanski, 1989; Douglas, 2002; Le Breton, 1992a, 1992b; Mauss, 1985; Scheper-Hughes \& Lock, 1987). Anthropological studies, however, go further. In order to change the focus from the 'representational' to the 
'experiential' study of culture, cultural researchers have been using a phenomenological perspective and, in doing so, the body has been considered more than an object in which the culture is 'written' and, therefore, 'read'. The body, in this perspective, is the subject of culture because we, as bodysubjects, learn culture firstly through the body, that is, before representing culture, we embody it (Alves \& Rabelo, 1998; Csordas, 1988, 1994a, 1994b, 1997; Rabelo \& Alves, 2001; Víctora, 1997). Organizational culture studies, however, have no research development taking advantage from this perspective.

Indeed, beyond the fact that the body is an (almost) absent presence (Dale, 2001) in organizational culture studies, it is important to highlight the prevalence of the cognitive (representational) paradigm in organizational culture research (Strati, 1998). This predominance appears clearly in Smircich's (1983) article summarizing the organizational culture research agenda. However, even though there are other and more updated researches revisiting the production in organizational culture studies (Alvesson, 2002; Martin, 1992, 2002; Martin \& Frost, 1996), Smircich's categorization is still updated and fits better in the analysis we are doing in this article.

In analyzing the studies that consider culture as a root metaphor for conceptualizing organization, Smircich (1983) organizes this theoretical production into three categories: organizational cognition, organizational symbolism, and unconscious process and organization. The first, which is based on cognitive anthropology, believes that culture is a system of shared knowledge. For the second, which is based on symbolic anthropology, culture is a system of shared meaning. In the last category, which is based on structural anthropology and psychodynamic theories, culture is considered as the manifestation and expression of the mind's unconscious operations.

Dandridge et al. (1980) and Schein (1984) can be quoted as examples of the unconscious process and organization category. In both articles organizational culture is related to unconscious assumptions (as well as feelings, images, and values) that determine how group members perceive, think, and feel the organization. In bringing the idea of the 'unconscious' as a means of understanding organizational culture, those studies propose a great development to this field of study but they are still attached to the cognitive perspective of understanding culture. Indeed, 'unconsciousness' composes a field of study that is concerned about mental (and not body) activity.

The idea that organizational culture is a system of meanings - symbolic anthropology (Alvesson, 2002; Gregory, 1983; Pettigrew, 1979), or a system of values - cognitive anthropology (Dandridge et al., 1980; Schein, 1984), is also about the rational-representational study of culture. In those perspectives, organizational action is analyzed as a consequence of a previous 
rational analysis (even symbolic or unconscious) meaning that it is the mind that impels human actions (Pettigrew, 1979) and motivates human behavior (Gregory, 1983). Although dealing with the higher mental functions of human behavior, such as language and the creation of meaning (Smircich, 1983), it is always the human consciousness interpretation of culture that those studies are talking about, never about the pre-reflective (embodied) relation that is dynamically built between organizational actors and organizational culture.

So, organizational researchers understand well organizational culture from a rational-representational perspective. However, we know less about organizational culture from bodily experience. In fact, much less has been studied about processes preceding cultural representation, such as the prereflective relation people establish with the organizational environment. From this point of view, the body becomes the foundation of experience (MerleauPonty, 2005) and, therefore, the existential locus of culture (Alves \& Rabelo, 1998; Csordas, 1988, 1994a, 1997). Therefore, let us turn to Anthropology and analyze how studies in this field deal with the relationship between culture and embodiment.

\section{Embodiment and culture}

The body has been studied in Social and Human Science from a representational and political perspective. Ontologically, both areas focus on the body as an artifact. From a representational approach, the perception of the body (Achutti, 1995), its practices (Hertz, 1980; Mauss, 1985), parts (Schiebinger, 1987), processes (Leal, 1995; Lock, 1996), and products (Farmer, 1988) are vehicles to unveil culture. From a political point of view, the body is an artifact embedded in power relations and mechanisms of control throughout processes of socialization (Elias, 1998; Foucault, 1979, 1990). From these two perspectives, we can understand the body as a social, cultural, political and historical object, rather than a biological entity.

\section{Body as experience: I am, therefore I think}

Contrasting with the idea of the body as an artifact, we can conceive the body as experience. This means refuting the Cartesian principle of 'I think, therefore I am' that sustains the split between body and mind. Under this dichotomization, while the body is a passive biological object, the rational mind is the human essence, the instance that assures clarity of thought and free will (Burkitt, 1999). In fact, Cartesian dualism sustains the logic of superiority of reason over emotion, subject over object, and mind over body. 
In contrast, embodiment is about overcoming Cartesian dichotomies through the study of our existential immediacy in a world that precedes reflective thought - the one that creates a world of objects (in which we are one of those) and the culture as a system of representations of those objects (Alves \& Rabelo, 1998). For Merleau-Ponty (2005: vii), reflection stands upon an unreflective experience because 'the world is always "already there" before reflection begins'. 'Being-in-the-world' is a traditional term from Phenomenology (Heidegger, 1996; Merleau-Ponty, 2005) that tells about this pre-reflective relation that we construct with the world.

It is through the experience of perceiving that we construct this prereflective, this experiential immediacy with the world (Merleau-Ponty, 2005). In a phenomenological perspective the experience of perceiving cannot be explained as something referring only to the sphere of sensation, emphasizing the biological sense that is implied by this term. It comprises a significant (historical and cultural) configuration of sensations, which means that perception is both (and inseparably) sensible and significant (Merleau-Ponty, 2005). More than that, the philosopher sustains that perception occurs externally (in the world) and not 'inside' a rational mind, meaning that perception is relational and occurs from an embedded relationship (and nondichotomic) between the individual (body) and the world.

Merleau-Ponty (2005) also stresses that perception does not refer primarily to contemplation, but to practical involvement. Perception is not a means, an instrument; it is an end in itself. Action and perception are intertwined and they take place in the course of individuals' actions always related (not necessarily consciously) to purposes and objectives. It is during this process that things become meaningful; that signification is not yet representational, but rather perceptual. Since our starting point in the world is the experience of perceiving, it is the body that offers us the possibility of being in relation to other people and objects through its capacity of seeing, hearing, smelling, tasting, feeling, touching, exploring, and wondering.

From a phenomenological perspective, the human being is conceived as an indivisible unity that is tightly held in a world that is, at first, not rationalized but experienced. Since it is the relational, practical, sensible and significant experience of perceiving that provides us with the first contact with the world, we cannot any longer consider ourselves as something that is inside a body (a soul, a mind, a consciousness). Instead of having a body, we have to consider that we are a body and that through the body we experience the world and learn. So, via phenomenology and 'carnal sociology' (Crossley, 1995), embodiment refers to a re-achievement of a direct and primitive contact with the world, the experience of 'being-in-the-world'. 


\section{Culture as embodied experience}

In order to understand embodiment and organizational culture, we capitalize on the pioneering key anthropological study of Csordas (1988) about embodiment and culture. This anthropologist wants to understand how the reflective process of the intellect elaborates cultural representations from the raw material of perception, which means that he intends to invert the analysis from the 'cultural constitution of perceptual categories' to the 'perceptual constitution of cultural objects'. In this case, cultural representation is rather considered as an abstraction of a previous corporeal cultural experience.

More precisely, Csordas (1988) used the embodiment perspective on his own research about healing and ritual language in a contemporary North American Christian religious movement. In studying the embodied imagery in the 'casting out of evil spirits' healing ritual, for example, Csordas (1988) wants to distinguish the already constituted object evil spirit from the experience of being released from evil.

When analyzing how Charismatic Christianity constitutes evil spirits as cultural objects, Csordas (1988) detects a similar characterization from the demonology of the Middle Ages in which the evil spirit is a being that harasses, oppresses, or possesses humans. Intertwined with this representation of evil is the discourse of interiority/exteriority which appears in the idea that the evil spirit has to be 'expelled' from the host's body and that the physical manifestations of this 'expulsion' are 'signs'.

In order to analyze the healing ritual phenomenologically, which means an embodied study of culture, Csordas (1988) begins from the physical manifestation - vomiting, writhing on the floor, hissing, rolling the eyes to the top of the head, shrieking like a hyena, and so on - that occurs when the demons transgress 'body boundaries'. According to Csordas (1988: 15), 'the preobjective element of this process rests in the fact that participants (...) experience these manifestations as spontaneous and without preordained content'. Indeed, even though the manifestations are experienced as spontaneous, considering spontaneity as a pre-reflective relation with the world, this spontaneity is not pre-cultural, since the physical manifestation of the 'casting out of evil spirits' occurs according to the cultural environment of the informant. From a phenomenological perspective, the vomiting, the writhing on the floor, the hissing, the rolling of the eyes to the top of the head and the shrieking like a hyena must be analyzed as 'a deeply ingrained somatic component of the experience and the symbolism of the evil in North America' (Csordas, 1988: 17).

With this analysis, Csordas (1988) highlights that people do not feel the demon as a cultural object inside themselves. They rather sense it as a 
thought, behavior, or emotion that is outside their control. In this specific healing ritual what occurs is a transgression or surpassing of a tolerance threshold defined by intensity, generalization, duration, or frequency of distress' (Csordas, 1988: 15-16). This interpretation challenges representational description of evil spirits (interiority/exteriority language) and discovers one that appears to have as much or greater experiential immediacy: the control/release language.

The healer stresses 'release' from bondage to the evil spirit, the afflicted people emphasize the lack of control when they are under evil spirit domination and the sensation of being released after the Charismatic Christian healing ritual. Csordas (1988) remembers that this pre-objective experience is not pre-cultural since control is a widespread theme in the cultural context of North America. Specifically, the loss of control in the Charismatic Christian context is analyzed as a demonic influence (negative value) and the restoring of self-control as God's intervention (positive value).

So, in using the embodiment to study this healing ritual Csordas (1988) reaffirms the phenomenological idea that we carry the social inseparably with us before any objectification' (Csordas, 1994b: 270), because we, as bodies, are in a historical and cultural world from the beginning. Considering that the body is where perception begins, the embodiment turns into a consistent perspective to understand the pre-reflective cultural processes because culture is embodied from the outset.

\section{Embodying culture through ritual}

Inspired by the study of Csordas (1988), we will focus on ritual because it is a fecund way to scrutinize the embodied dimension of organizational culture. When we say ritual, we also include rite. As ritual and rite are closely related and as some prominent scholars have used rite and ritual as interchangeable concepts (Gennep, 1966; Rivière, 1995; Segalen, 1998; Turner, 1995), we do not establish a significant distinction between these two terms.

Furthermore, rather than considering ritual from a functional and symbolic point of view (Curran, 1989; Gennep, 1966; Rivière, 1995; Turner, 1995 ) or as a management tool to achieve efficiency and effectiveness (Deal \& Kennedy, 1982; Harris \& Sutton, 1986; Trice et al., 1984), we understand it as an embodiment experience (Bell, 1992; Csordas, 1988). Consequently, rituals are more than a support for symbols and signs or an object in which the memory of the culture is unscripted. From an embodied perspective, rituals do not represent the culture. Rather, they are the experience of the culture. In other words, the ritualized body is not a modus operandi for the work of culture: what the body performs during the ritual 
are ends in themselves because the embodied selves inhabit a behavioral environment that is superior to any single ritual event (Csordas, 1988).

Ritualization produces thus a ritualized body through the interaction of the body with a structured and structuring environment. When performing a ritual, the body internalizes the principles of the environment and generates different schemes that can be used in other situations or rituals (Bell, 1992). In the ritual, body movements become socially instinctive automatisms, occurring before either personal consciousness or social discourse explicitness. That is, it occurs as pre-reflective behavior rooted in the socio-cultural body revealing an understanding of ritual from a nondualistic and embodied perspective.

In this study, we seek to investigate the embodied dimension of organizational rituals, focusing on rituals organized by employees in relatively informal situations, such as the after-work drinking ritual.

\section{The after-work drinking ritual: Let's have a beer?!}

We can say that participating in happy hours with work colleagues is a normal after-work ritual. During the ritual, drinking alcohol is a popular behavior that is directly related to bodily matters. Culturally speaking, alcohol ingestion has the potential of inebriating and altering our state. In this context, non-routine behavior is accepted and conventional organizational relations are suspended (Harris \& Sutton, 1986; Rosen, 1988; Trice \& Beyer, 1984). Indeed, alcohol consumption affects the integrity of the self and makes pre-reflective processes more evident in analytical terms. We will focus specifically on a bookstore salespersons' after-work beer drinking ritual that occurs inside restaurants or bars and where the employees are out of reach - literally or symbolically - of the performance expectations of those who supervise them and those they serve (Fineman, 1993). It is precisely this environment of 'spontaneity' that is of interest in examining the embodiment of organizational culture. The empirical research is based on ethnography.

\section{Methodology}

BBook is one of the biggest Brazilian bookstore networks, having six shops in four capitals and employing more than 600 people. The company is almost 40 years old and has the philosophy of 'disseminating culture', the mission of 'charming the client, making her/his interaction with BBook's products and services a pleasant experience, based on a competent, creative and agile 
assistance' and with the most important value of 'never losing a client'. BBook's guidelines are part of the corporate strategy and they are presented to employees in the corporate human resource manual.

For a six-month period one of us (Mary) worked at BBook as a participant observer. Mary acted as an observer, mostly interested in the salespersons' group. During the field observation, she participated in a BBook's salespersons' routine at work and leisure. In the sales saloon - where she used to stay three or four days a week, six or seven hours a day - Mary helped her 'colleagues' in organizing bookshelves, searching for missing books, and doing some simple attendance work. Besides sales activities, she also participated in one new employee training session, three board-employee meetings and one salesperson's selection process. As time went by and Mary became progressively a trustable 'colleague', she started being invited to participate in many leisure activities, such as a dancing party in the house of a 'colleague', a bar party in which this 'colleague' was the DJ, a rock concert, a birthday party in a disco, and in three after-work drinking rituals.

Many devices were used to deal with field information. At the company, she carried a notepad that she used daily and regularly to take notes on field observations. In subsequent days, she reviewed her notes, rewriting them into a diary format (Malinowski, 1967). In the context of leisure activities, Mary did not take notes during the event, since she felt it could be perceived as an inconvenient act by participants in the ritual. She chose to write the field diary immediately, the day after the leisure activity took place.

Analysis is a process that covers all processes of interaction with empirical material (Alvesson \& Sköldberg, 2000), even though we have used Nvivo to better organize and analyze field information. Indeed, all notes were coded regarding different situations and events that could allow a clear understanding of organizational culture embodiment. Next, the beer drinking ritual was selected as the most representative and richest event. Consequently, we recoded information about this ritual considering three specific moments (September, November and December meetings) and situations illustrating organizational culture and embodiment simultaneously.

Our focus on a nonofficial organizational ritual in which alcoholic beverages are the main product consumed shows that even in an environment of apparent spontaneity the embodied organizational culture remains perceptible. However, it is important to highlight that even though the after-work beer ritual is the main source of information for understanding BBook's culture, field work goes further (participant observation in sales department, corporate meetings, leisure celebrations with the team, and reading corporate 
documents), which enables us to make sense of an external organizational ritual in the context of organizational culture.

\section{The after-work beer drinking ritual}

Mary participated in three after-work beer drinking rituals in which a small group of BBook's employees joined together to drink beer, smoke and talk, specifically about the company. The first meeting was held in September, the second in November and the third in December. In those informal meetings, there were always three salespersons that were the most engaged in the meeting's organization: Victor, Margaret and Bronislaw. Besides them and Mary, two former salespersons participated in the rituals (Catherine in the September meeting and David in December), and three other sales employees (Franz in the September ritual, Karen and John in November). The presence of former salespersons in those meetings occurred because they were very good friends of the ritual participants. Mary's husband, Clifford, also participated in the November meeting.

Selection of the meeting place was mostly conditioned by the cost of beer and permission to smoke. To participate in this after-work ritual you have to drink, especially beer. The quantity of alcohol ingested should be enough for participants to be culturally classified as 'a little bit high', that is, not totally drunk but released to execute some non-routine behavior and to suspend some regular social relations. In the analysis, Mary observed that during the after-work drinking ritual the participants experienced a distinctive bond regarding BBook's culture in terms of pre-reflexivity. Let us thus describe those rituals in order to make an embodied understanding of organizational culture.

The September and December beer rituals were similar in some aspects. They were held in a restaurant and after a cultural event that Victor organized in the bookstore. The conversation, emotions and gestures were very similar and in both rituals former BBook salespersons participated. Drinking beer, smoking and talking about company subjects were the main topics. What was also repetitive in both events was the conversation about 'uncommitted' colleagues.

In the September meeting Jay's conduct was evaluated by the group. According to them, Jay hurt his knee in a soccer game and got a medical leave for a long period. The group was very irritated and angry with the situation since they considered it as a sign of non-commitment. While Franz talked about Jay's case, he gesticulated a lot, especially pointing and shaking his finger to the rest of the group, speaking loudly and with a furious 
intonation. This behavior caught Mary's attention since the first time she met Franz in the BBook sales saloon he was extremely polite, had a velvet voice and smooth body movements.

It was almost unanimous: Jay should be punished in some way because of his 'uncommitted' behavior. Catherine, a former BBook employee, was the only one that tried to argue saying 'Life is not only the bookstore!' loudly. The rest of the group did not listen to her and kept talking furiously about the possibility of firing Jay and thinking about what they could do to make this happen. Similarly, in the December drinking ritual another salesperson (Joanna) was evaluated during a ritual.

Joanna, who worked in the Art section of BBooks, made an agreement with her previous department manager about her work schedule for November. In that month, she would work part-time since she was involved in an important Art exhibition that takes place every two years in the city. The current manager, according to Margaret and Victor, was not happy with this arrangement. During the drinking ritual, Margaret, speaking loudly, showed how irritated she was at this advantage that was 'offered' to Joanna. David, a former BBook employee, stood up for Joanna arguing as Angela did in relation to Jay: 'There is a world out there!' David also said that they, the ritual leaders, were turning into 'The Murphys', which is the surname of the family that owns the bookstore. After that observation, both Margaret and Victor calmed down. Their bodies seemed to become 'smaller', less 'swollen' and they started analyzing their situation. Margaret said that she had been 'abducted' and that her life was 'brown'; after saying that, she laughed. She also said that in her days off she liked to sleep in the afternoon because it was when she had good dreams. She dreamed that she was flying and had a sensation of freedom. Victor also talked about his situation. He said that the reason why he was working at BBook was because he had no other options and because his financial life was a mess. Thus, he made a joke saying that he was 'flat broke' but watching TV with double surround equipment. Everybody laughed.

September and December meetings were very intense and participants were mostly concerned with discussing 'uncommitted' colleagues. In discussing Jay's medical license and Joanna's temporary work schedule the group started talking compulsively, loudly and using a threatening tone of voice. 'Pointing and shaking the finger' was a body movement much used by the members while they were conspiring about their work colleagues and it felt like anger was the most frequently expressed emotion in both rituals. Those ritual physical experiences cannot be considered as pre-cultural since they occur according to the cultural environment of ritual participants. When they speak compulsively, using a threatening tone of voice and body 
movements such as pointing and finger shaking, they are embodying an autocratic behavior because those expressions are a deeply ingrained somatic component of the experience and the symbolism of authority in Brazil (as with many other cultural groups).

Autocratic authority is a very traditional commanding style in many social situations, such as family, politics, church and organizations. In this commanding style there is a person, or a small group of people, using their authority to define and control behaviors in the social environment they are in charge of. This is a commanding style that is also very much present in the everyday work routine of BBook and that could be seen, for example, in the manner some directors act, constantly camera monitoring the team, in the efficient computer information systems that track all employees' operations, and finally, in the high level of control and demand for a service that challenges employees to 'never lose a client' through a 'competent, creative and agile assistance'.

It is interesting to note that in December's ritual the participants' physical arrangement changed when a former BBook employee, David, said they were turning into 'The Murphys'. According to Mary's field notes, after this intervention Margaret's and Victor's bodies became 'smaller', less 'swollen' and their tone of voice returned to a regular volume while they started talking about their real life condition (abduction sensation, 'brown' life, lack of freedom and 'flat broke' situation). This radical change in physical arrangement can be phenomenologically analyzed as the embodiment of a cultural experience of losing power and authority.

The November after-work drinking ritual was more festive. The meeting was held in the bar of a bingo house inside the shopping mall. This time there were no former employees participating. Victor, Margaret and Bronislaw were there again and two new salespersons were added to the group: Karen and John. Mary's husband, Clifford, also participated intensively in the ritual. People started drinking, talking and smoking. At first, small groups were formed: Victor, Margaret and Bronislaw; John and Karen; Mary and Clifford. The fact that the group was standing, increase in the quantity of beer consumed and offer of a ride to everybody by Mary and Clifford are some of the causes for the subsequent integration of this group. This integration was observed through a louder tone of voice in the conversation, more laughter, a more frequent body contact between people in the group, especially hugs and kisses, dance steps and increase in cigarette consumption by smokers, even by Mary, who had not smoked for six months.

During a conversation, Mary's husband learned about an administrative procedure formally called 'donation'. Donation refers to any book 
donated to the customer to compensate him/her for any problem during the sales process. The point is that this is not a corporate donation; the person responsible for it is the employee who makes a mistake during the sale. Mary's husband created a swear word to describe his feeling in relation to this procedure. The group liked it and started repeating it loudly. Right after, Victor created another swear word also to refer to the donation of books. That was a euphoric moment, with everybody repeating both swear words and laughing about it.

As a consequence of all the beer drinking, happiness, cigarettes, loud voices and bodily contact, the security guard of the bingo house complained about the noise made by the group, saying that the 'party' was 'disturbing the machines'. Retaliation against the establishment began. The group started claiming for their consumers' rights, speaking louder than before and throwing cigarette ash on the floor. After drinking much beer they decided to pay and return home. While the group was walking down the bingo house's stairs, everybody put sunglasses on, although it was night and they were inside a shopping mall, and started faking laughter as a protest against the security guard's complaints.

The November ritual was also very intense, but in a different way. The effects of drinking were more associated with celebration and contestation. Anger was still present, but now it was addressed to BBook's managerial rules and to the bingo bar authorities. Instead of analyzing 'uncommitted' colleagues, corporate demand for constant competence and discipline was the subject being questioned in this ritual.

For challenging and criticizing BBook's constant demands for competence, the group laughed and often repeated the new swear word created by Mary's husband to describe his feeling about the administrative procedure called 'donation'. In addition to this idea, Victor also created a new swear word which was also repeated as if they were singing a song, moving their bodies as if they were performing a little dance. The ritualistic way participants found to challenge the bingo bar authority was also a creative protest. A creative retaliation against the establishment began after the security guard complained. Everybody started talking and laughing louder than before, throwing cigarette ash on the floor and, at the end, putting sunglasses on to play about hiding their identities.

So, once again, although participants' body manifestations are experienced as spontaneous, they did not overstep a specific repertoire of physical arrangements. In this case, the ritual behavior is related to a cool and contesting cultural experience. Being cool and contesting is directly related to an alternative cultural environment that usually involves young people, music, night parties, alcoholic beverages, smoking and intellectual affinities. This 
cultural alternative environment has a historical reference, and the politicalcultural events of the 1960s stand out as a major landmark. It was a time of sexual liberation, youth empowerment, drug culture, rock and roll, including the cultural-political events surrounding May 1968 in Paris.

It is important to remember that BBook's philosophy is to 'disseminate culture' (in this case, we are talking about a cult-erudite culture) and one of its missions is to provide creative assistance to its customers. In order to achieve those guidelines, the organization has some selection techniques, such as an examination that tests applicants for a sales job about literature, music, magazines, and so on. About salespersons' visual appearance, the company has chosen not to homogenize the team with traditional uniforms and the possibility is there for alternative body ornamentation (tattoos, piercing, different hairdo and colored hair). BBook also has some cultural benefits such as a partnership with a movie theater that sells cheaper movie tickets, and a book loan system in which every month any employee can borrow up to five books and, finally, they have special discounts for employees buying products from the shop (CDs, DVDs, books and magazines). Above all, BBook's board demands that the sales team, in particular, has creative ideas, such as organizing cultural events in the shop.

Finally, regarding the anger that was present in all three rituals, it does not reflect a mental-emotional state of a person or group that we are discussing. Anger cannot be separated from words, gestures and body because we actually do not express anger, we (corporeally) feel angry (Merleau-Ponty, 2004). Therefore, anger is, rather, an embodied state of a self that in the after-work drinking ritual is released to experience BBook's organizational culture distinctively. Through the ingestion of alcoholic beverages and being in an environment where public courtesies or emotional control can be relaxed (Fineman, 1993), ritual participants seem to feel free to experience anger at working in such demanding and controlling conditions.

\section{Rethinking organizational culture from embodiment: Discussion and implications}

Analysis of the beer drinking ritual at BBook allows us to understand how organizational culture is not only a matter of sense-making and representational processes, but also something that is first learned in the experiential immediacy by a sensible-significant body-subject. When we pay attention to the experiential immediacy of organizational culture, we focus on this moment of pre-reflectivity that allows a full experiencing of culture via body 
perception. In the experiential immediacy culture is not yet representational, but rather perceptual.

In this article experiential immediacy of organizational culture is grasped in moments of leisure, when employees go out to drink beer and interact. Due to the 'out of reach' territorial sensation and the alcoholic biological inebriating effect, employees feel like experiencing spontaneity, but in an embodied analysis this spontaneity is not pre-cultural since it translates organizational culture (among other culture references, such as popular, occupational, family or national culture) in the immediacy of lived experience.

For example, during the discussion, with the playfulness and emotionladen atmosphere that takes place in the beer ritual, employees think they expand their personal knowledge, being more than what is expected by the organizational culture to become more subjectively close to work colleagues. However, they do not necessarily realize that they relate to values and symbols shaped by the company. As we have seen, gestures, emotions, tone of voice and even the language used in the drinking ritual are related to the cultural (organizational and socio-historical) experiences of authority, creativity and cult-erudite culture. Even anger, remembering that in an embodied perspective anger is not considered as something we express, but something we (corporeally) feel; it is analyzed as something related to BBook's culture. Ritual participants experience anger bodily and collectively and its sense is analyzed as a protest against the experience of a strong demand and control they have in BBook's environment.

From this embodied perspective, organizational rituals can also be distinguishingly conceived from current organizational cultural analyses. Rituals are more than a representation (functional or symbolic) of organizational culture, they are also a medium for experiencing the culture. Differently from what organizational culture studies have been arguing (Martin, 2002; Trice \& Beyer, 1984) what the body performs during the ritual is not (at least not only) a support for symbols and signs. From an embodied perspective, ritualistic body performance is considered as socially instinctive automatisms, occurring before either personal consciousness or social discourse explicitness (Bell, 1992; Csordas, 1988).

Therefore, if organizational culture studies have enriched researchers' understanding about the representational dimension of organizational values and symbols, focus on culture-embodiment relationship has allowed us to go further and understand that sense making and culture have a pre-reflective component; they are processes taking place in the immediacy, spontaneity and instinctive automatism of cultural experience at the workplace. It is during this process that organizations become meaningful; that signification is not yet representational, but rather perceptual. Organizational culture, 
therefore, is more than a cognitive-representational abstraction; it is also a perceptual-embodied experience. The after-work drinking ritual provided us with material and insight for this understanding.

\section{Conclusions}

The purpose of this research was to help organizational researchers enrich their understanding of organizational culture phenomena. This rethinking was possible by focusing on the embodied dimension of organizational culture and its theoretical implications. We focused on the anthropological study by Csordas (1988) on religious rituals and on the experience by one of the authors, who participated in and observed a group of employees at a workplace and engaged in after-work drinking rituals.

In order to study this ritual from an embodied perspective, we analyzed body performances (gestures, tone of voice, emotions, body posture, bodily contact and language) not as representations of organizational culture, but as the own experience of culture. Ritualized body performance, in this analysis, is more than symbols or social function representations; it is socially instinctive automatism that occurs before any cognitive process of cultural representation.

Then, when we focused on the organizational ritual as something that is experienced and in which the body is the royal subject of culture, we emphasized the necessity of focusing on the pre-reflective employee-organization relation. This pre-reflective relation occurs in the experiential immediacy that exists through relational, practical, sensible and significant perceptual experience between employees and the organizational world. The analysis of this pre-reflective (embodied) relationship improves organizational researchers' understanding of organizational culture showing that culture is more than a cognitive-representational abstraction: organizational culture is also a perceptual-embodied experience. We hope that these findings may inspire a fresh and fecund direction in organizational culture studies, one that challenges the current scenario dominated by the cognitive (representational) perspective in this field of study.

\section{Acknowledgements}

We are grateful to the guest editors Andrew Sturdy and Rob B. Briner and the three anonymous reviewers of the Human Relations for their helpful comments and suggestions. We are also grateful to $\mathrm{CNPq}$, which provided financial support for this research. 


\section{Note}

1 All the names in the ethnographic description are pseudonyms.

\section{References}

Achutti, L.E. Imagem e fotografia: aprendendo a olhar. In O. Leal (Ed.), Corpo e significado: ensaios de antropologia social. Porto Alegre: Ed. Universidade/UFRGS, 1995, pp. 423-34.

Alves, P.C. \& Rabelo, M.C. Repensando os estudos sobre representações e práticas em saúde/doença. In P.C. Alves \& M.C. Rabelo (Eds), Antropologia da saúde: Traçando identidades e explorando fronteiras. Rio de Janeiro: Relume Dumará, 1998, pp. 107-21.

Alvesson, M. Understanding organizational culture. London: SAGE, 2002.

Alvesson, M. \& Sköldberg, K. Reflexive methodology. New vistas for qualitative research. London: SAGE, 2000.

Bell, C. Ritual theory, ritual practice. New York: Oxford University Press, 1992.

Boltanski, L. As classes sociais e o corpo. Rio de Janeiro: Graal, 1989.

Burkitt, I. Bodies of thought: Embodiment, identity and modernity. London: SAGE, 1999.

Crossley, N. Merleau-Ponty, the elusive body and carnal sociology. Body \& Society, 1995, $1,43-63$.

Csordas, T.J. Embodiment as a paradigm for anthropology. Ethos, 1988, 18, 5-47.

Csordas, T.J. Embodiment and experience: The existential ground of culture and self. Cambridge: Cambridge University Press, 1994a.

Csordas, T.J. Words from the holy people: A case study in cultural phenomenology. In T. Csordas (Ed.), Embodiment and experience: The existential ground of culture and self. Cambridge: Cambridge University Press, 1994b, pp. 269-90.

Csordas, T.J. The sacred self: A cultural phenomenology of charismatic healing. Los Angeles: University of California Press, 1997.

Curran, P. Grace before meals: Food ritual and body discipline in convent culture. Urbana and Chicago: University of Illinois Press, 1989.

Dale, K. Anatomising embodiment and organization theory. Basingstoke: Palgrave, 2001.

Dandridge, T., Mitroff, I. \& Joyce, W. Organizational symbolism: A topic to expand organizational analysis. Academy of Management Review, 1980, 5, 77-82.

Deal, T.E. \& Kennedy, A.A. Corporate cultures: The rites and rituals of corporate life. Reading, MA: Addison-Wesley, 1982.

Douglas, M. Purity and danger. London: Routledge, 2002.

Elias, N. The civilizing process sociogenetic and psychogenetic investigations. Oxford: Blackwell, 1998.

Farmer, P. Bad blood, spoiled milk: Bodily fluids as moral barometers in rural Haiti. American Ethnologist, 1988, 15, 62-83.

Fineman, S. Organizations as emotional arenas. In S. Fineman (Ed.), Emotion in organizations. London: SAGE, 1993, pp. 9-35.

Foucault, M. Discipline \& punish: The birth of the prison. New York: Vintage Books, 1979.

Foucault, M. The history of sexuality: An introduction. New York: Vintage Books, 1990.

Geertz, C. The interpretation of cultures: Selected essays. New York: Basic, 1973.

Gennep, A.V. The rites of passage. Chicago, IL: University of Chicago Press, 1966.

Gregory, K.L. Native-view paradigms: Multiple cultures and culture conflicts in organizations. Administrative Science Quarterly, 1983, 28, 359-76.

Harris, S. \& Sutton, R. Function of parting ceremonies in dying organizations. Academy of Management Journal, 1986, 29, 5-30. 
Hatch, M.J. The dynamics of organizational culture. Academy of Management Review, 1993, 18, 657-93.

Heidegger, M. Being and time: A translation of Sein und Zeit. New York: State University of New York Press, 1996.

Hertz, R. A preeminência da mão direita: um estudo sobre a polaridade religiosa. Religião e Sociedade, 1980, 99-128.

Latouche, D. The organizational culture of government: Myths, symbols and rituals in a Quebecois setting. International Social Science Journal, 1983, 35, 257-78.

Le Breton, D. Anthropologie du corps et modernité. Paris: Presses universitaires de France, 1992a.

Le Breton, D. La sociologie du corps. Paris: Presses universitaires de France, $1992 \mathrm{~b}$.

Leal, O. Sangue, fertilidade e práticas contraceptivas. In O. Leal (Ed.), Corpo e significado: ensaios de antropologia social. Porto Alegre: Ed. Universidade/UFRGS, 1995, pp. 15-36.

Lock, M. Death in technological time: Locating the end of meaningful life. Medical Anthropology Quarterly, 1996, 10, 575-600.

Malinowski, B. A diary in the strict sense of the term. Stanford, CA: Stanford University Press, 1967.

Martin, J. Culture in organizations: Three perspectives. New York: Oxford University Press, 1992.

Martin, J. Organizational culture: Mapping the terrain. Thousand Oaks, CA: SAGE, 2002.

Martin, J. \& Frost, P. The organizational culture war games: A struggle for intelectual dominance. In S.R. Clegg, C. Hardy \& W.R. Nord (Eds), Handbook of organization studies. London: SAGE, 1996, pp. 599-621.

Mauss, M. Sociologie et anthropologie. Paris: Presses de l'Université de France, 1985.

Merleau-Ponty, M. The world of perception. London: Routledge, 2004.

Merleau-Ponty, M. Phenomenology of perception. New York: Routledge, 2005.

Pettigrew, A.M. On studying organizational cultures. Administrative Science Quarterly, 1979, 24, 570-81.

Rabelo, M.C. \& Alves, P.C. Corpo, experiência e cultura. Paper presented at the XXV Encontro Anual Da Anpocs, Caxambu, 2001.

Rivière, C. Les rites profanes. Paris: Presses de l'Université de France, 1995.

Rosen, M. You asked for it: Christmas at the bosses' expense. Journal of Management Studies, 1988, 25, 463-80.

Schein, E. Coming to a new awareness of organizational culture. Sloan Management Review, 1984, 25, 3-16.

Schein, E. Organizational culture and leadership. San Francisco, CA: Jossey-Bass, 1992.

Scheper-Hughes, N. \& Lock, M. The mindful body: A prolegomenon to future work in medical anthropology. Medical Anthropology Quarterly, 1987, 1, 6-41.

Schiebinger, L. Skeletons in the closet: The first illustration of the female skeleton in eighteen-century anatomy. In C. Gallagner \& T. Laqueur (Eds), The making of the modern body: Sexuality and society in the nineteenth century. London: University of California Press, 1987, pp. 42-82.

Segalen, M. Rites et rituels contemporains. Paris: Nathan, 1998.

Smircich, L. Concepts of culture and organizational analysis. Administrative Science Quarterly, 1983, 28, 339-58.

Strati, A. Organizational symbolism as a social construction: A perspective from the sociology of knowledge. Human Relations, 1998, 51, 1379-402.

Trice, H.M. \& Beyer, J.M. Studying organizational cultures through rites and ceremonials. Academy of Management Review, 1984, 9, 653-69.

Turner, V. The ritual process: Structure and anti-structure. New York: Aldine de Gruyter, 1995.

Víctora, C. Inside the mother's body: Pregnancy and the 'emic' organ 'the body's mother'. In A. Leibing (Ed.), The medical anthropologies in Brazil. Berlin: VWB, Verlag für Wissenschaft und Bildung, 1997, pp. 169-75. 
Maria Tereza Flores-Pereira is a professor of Organization Theory and People Management at Catarinense Plateau University (UNIPLAC), Brazil. Her interests concern studying organizational culture, aesthetic, socio-cultural body and embodiment. Her current research focus is on the relationship between culture, aesthetics and embodiment within organizations, such as restaurants. She is also an associate researcher with the School of Management at the Federal University of Rio Grande do Sul (UFRGS) and with the Center for Organization Studies and Symbolism (NEOS) at the School of Economics of the Federal University of Minas Gerais (UFMG), Brazil.

[E-mail: mtfpereira@terra.com.br]

Eduardo Davel is professor of Organization and Management Studies at Télé-université (TELUQ), the distance learning university within the Université du Québec à Montréal (UQAM), Canada. His interests include the study of management through the lens of sociocultural, aesthetic, emotional and socio-practice issues. His current research focuses on entrepreneurship, management and career in creative industries. $\mathrm{He}$ is also the associate editor of the RAE Journal, published by FGV-EAESP (São Paulo) and associate researcher with the Interdisciplinary Center for Social Development and Managing at the School of Management of the Federal University of Bahia, Brazil. Publications include books on Subjectivity and management (Editora Atlas, 200I), Arts and management learning (Editora Atlas, 2007) and Intercultural management (Presses de l'Université Laval, 2008).

[E-mail: davel.eduardo@teluq.uqam.ca]

Neusa Rolita Cavedon is an Associate Professor in the School of Management at the Federal University of Rio Grande do Sul (UFRGS) and a researcher of the National Council for Scientific and Technological Development (CNPq), Brazil. She holds a master's and a doctor's degree in Management and a master's degree in Social Anthropology from the Federal University of Rio Grande do Sul. Her research interests focus on organizational cultures, identity and social representations. Publications include books on Anthropology for managers (UFRGS, 2003, 2008), Social representations in health management (Dacasa, 2005) and Post-modernity and ethnography in organizations (EDUNISC, 2005, with Jorge Lengler); book chapters and articles in periodicals.

[E-mail: nrcavedon@ea.ufrgs.br] 